\title{
Preparation and Characterization of Nano-Dy $\mathbf{y}_{2} \mathrm{O}_{3}$-Doped PVA + $\mathrm{Na}_{3} \mathrm{C}_{6} \mathrm{H}_{5} \mathrm{O}_{7}$ Polymer Electrolyte Films for Battery Applications
}

\author{
J. Ramesh Babu $\mathbb{D}^{1}{ }^{1}$ K. Ravindhranath $\mathbb{D}^{2},{ }^{2}$ and K. Vijaya Kumar' \\ ${ }^{1}$ Department of Physics, K L University, Vaddeswarram, 522502 Guntur, India \\ ${ }^{2}$ Department of Chemistry, K L University, Vaddeswarram, 522502 Guntur, India \\ Correspondence should be addressed to J. Ramesh Babu; jallirameshura@gmail.com
}

Received 11 October 2017; Accepted 1 January 2018; Published 12 March 2018

Academic Editor: Frederic Dumur

Copyright $(2018$ J. Ramesh Babu et al. This is an open access article distributed under the Creative Commons Attribution License, which permits unrestricted use, distribution, and reproduction in any medium, provided the original work is properly cited.

Composite polymer electrolyte films containing various concentrations of nano- $\mathrm{Dy}_{2} \mathrm{O}_{3}(1.0$ to $4.0 \%)$ in PVA + sodium citrate $(90: 10)$ are synthesized adopting solution cast method and are characterized using FTIR, XRD, SEM, and DSC techniques. The investigations indicate that all components are homogenously dispersed. Films containing 3\% of nano$\mathrm{Dy}_{2} \mathrm{O}_{3}$ are more homogenous and less crystalline, and the same is supported by DSC studies indicating the friendly nature to ionic conductivity. Transference number studies reveal that the major charge carriers are ions. With the increase in $\%$ of nano- $\mathrm{Dy}_{2} \mathrm{O}_{3}$, the conductivity increases and reaches maximum in $3 \%$ film with a value of $1.06 \times 10^{-4} \mathrm{~S} / \mathrm{cm}(\mathrm{at} 303 \mathrm{~K}$ ). Further, the conductivity of the film increases with raise in temperature due to the hopping of interchain and intrachain ion movements and fall in microscopic viscosity at the matrix interface of the film. Electrochemical cells are fabricated using these films with the configuration "anode $(\mathrm{Mg}+\mathrm{MgSO} 4) /\left[\mathrm{PVA}(90 \%)+\mathrm{Na}_{3} \mathrm{C}_{6} \mathrm{H}_{5} \mathrm{O}_{7}(10 \%)+\left(1-4 \%\right.\right.$ nano- $\left.\left.\mathrm{Dy}_{2} \mathrm{O}_{3}\right)\right] / \mathrm{cathode}$ $\left(\mathrm{I}_{2}+\mathrm{C}+\right.$ electrolyte)," and various discharge characteristics are evaluated. With $3 \%$ nano- $\mathrm{Dy}_{2} \mathrm{O}_{3}$ film, the maximum discharge time of $118 \mathrm{hrs}$ with open-circuit voltage of $2.68 \mathrm{~V}$, power density of $0.91 \mathrm{~W} / \mathrm{kg}$, and energy density of 107.5 Wh/kg are observed. These findings reflect the successful adoption of the developed polymer electrolyte films in electrochemical cells.

\section{Introduction}

Solid polymer electrolytes are endowed with characteristics that are intermediate between the solid inorganic electrolytes and liquid electrolytes. These electrolytes by virtue of possessing good ionic conductivity, mechanical strength, and chemical, thermal, and electrochemical stabilities and furthermore good compatibility with the electrode materials are proving to be promising ingredients in electrochemical devices, fuel cells, supercapacitors, solar cells, electrochromic displays, and so on [1-5]. Many investigations are concentrating on improving the conductivity of the solid polymer electrolytes by chemically modifying the surface morphology to promote the formation of protecting layers of low resistivity at the electrolyte-electrode interface. But such surface modified polymer electrolytes are costly. Hence, investigations are being undertaken using multicomponent composite polymer films loaded with salts and inorganic compounds with an aim to enhance the conductivity by modifying the physicochemical properties of the blended films.

PVA-based polymer films are finding more importance in this regard as they form good films with high mechanical strength, and they are nontoxic. The surface functional groups such as $-\mathrm{OH}$ offer easy surface modifications [6-8].

Doping of nanoparticles in the PVA-based films with an aim to enhance the mobility of ions/electrons in the films besides stabilizing the films, is a relevant and recent development [9]. The nanoparticle-studded films are showing improved properties because the less surface area/volume ratio, quantum confinements, and other morphological changes attributed to the nanoparticles are influencing the conductivity of the films. Investigations are reported to the literature by doping nano- $\mathrm{Al}_{2} \mathrm{O}_{3}, \mathrm{TiO}_{2}, \mathrm{SiO}_{2}$, and $\mathrm{Fe}_{2} \mathrm{O}_{3}$ in PVA films with respect to different electrical properties [10-24].

In this present investigation, nano- $\mathrm{Dy}_{2} \mathrm{O}_{3}$-doped $\mathrm{PVA}+$ sodium citrate composite films are synthesized and characterized 
TABLE 1: DSC DATA pertaining to $T_{\mathrm{g}}, M_{\mathrm{p}}$, and \% of crystallinity of composite films.

\begin{tabular}{lcccc}
\hline Number & Film composition & $T_{\mathrm{g}}$ & $M_{\mathrm{p}}$ & $\%$ of crystallinity \\
\hline 1 & Pure PVA & 92.98 & 224.05 & 100 \\
2 & PVA $+\mathrm{Na}_{3} \mathrm{C}_{6} \mathrm{H}_{5} \mathrm{O}_{7}+\mathrm{Dy}_{2} \mathrm{O}_{3}(90: 10: 1 \%)$ & 89.26 & 223 & 78.27 \\
3 & $\mathrm{PVA}+\mathrm{Na}_{3} \mathrm{C}_{6} \mathrm{H}_{5} \mathrm{O}_{7}+\mathrm{Dy}_{2} \mathrm{O}_{3}(90: 10: 2 \%)$ & 87 & 222 & 72.50 \\
4 & $\mathrm{PVA}+\mathrm{Na}_{3} \mathrm{C}_{6} \mathrm{H}_{5} \mathrm{O}_{7}+\mathrm{Dy}_{2} \mathrm{O}_{3}(90: 10: 3 \%)$ & 85 & 221 & 65.26 \\
5 & PVA $+\mathrm{Na}_{3} \mathrm{C}_{6} \mathrm{H}_{5} \mathrm{O}_{7}+\mathrm{Dy}_{2} \mathrm{O}_{3}(90: 10: 4 \%)$ & 90 & 223 & 79.91 \\
\hline
\end{tabular}

TABLE 2: Ionic conductivity, activation energy, and transference numbers of PVA + sodium citrate + nano- $\mathrm{Dy}_{2} \mathrm{O}_{3}$ polymer electrolyte films at different compositions.

\begin{tabular}{|c|c|c|c|c|c|}
\hline \multirow{2}{*}{ Number } & \multirow{2}{*}{ Polymer electrolyte } & \multirow{2}{*}{$\begin{array}{c}\text { Conductivity at } \\
303 \mathrm{~K}(\mathrm{RT})(\mathrm{S} / \mathrm{cm})\end{array}$} & \multirow{2}{*}{$\begin{array}{l}\text { Activation } \\
\text { energy }\left(E_{a}\right)\end{array}$} & \multicolumn{2}{|c|}{ Transference number } \\
\hline & & & & $t_{\text {ion }}$ & $t_{\text {ele }}$ \\
\hline 1 & Pure PVA & $5.59 \times 10^{-10}$ & 0.42 & - & - \\
\hline 2 & $\mathrm{PVA}+\mathrm{Na}_{3} \mathrm{C}_{6} \mathrm{H}_{5} \mathrm{O}_{7}+\mathrm{Dy}_{2} \mathrm{O}_{3}(90: 10: 1 \%)$ & $5.31 \times 10^{-5}$ & 0.36 & 0.94 & 0.06 \\
\hline 3 & $\mathrm{PVA}+\mathrm{Na}_{3} \mathrm{C}_{6} \mathrm{H}_{5} \mathrm{O}_{7}+\mathrm{Dy}_{2} \mathrm{O}_{3}(90: 10: 2 \%)$ & $4.48 \times 10^{-5}$ & 0.28 & 0.97 & 0.03 \\
\hline 4 & $\mathrm{PVA}+\mathrm{Na}_{3} \mathrm{C}_{6} \mathrm{H}_{5} \mathrm{O}_{7}+\mathrm{Dy}_{2} \mathrm{O}_{3}(90: 10: 3 \%)$ & $1.06 \times 10^{-4}$ & 0.19 & 0.98 & 0.02 \\
\hline 5 & $\mathrm{PVA}+\mathrm{Na}_{3} \mathrm{C}_{6} \mathrm{H}_{5} \mathrm{O}_{7}+\mathrm{Dy}_{2} \mathrm{O}_{3}(90: 10: 4 \%)$ & $3.26 \times 10^{-6}$ & 0.26 & 0.93 & 0.07 \\
\hline
\end{tabular}

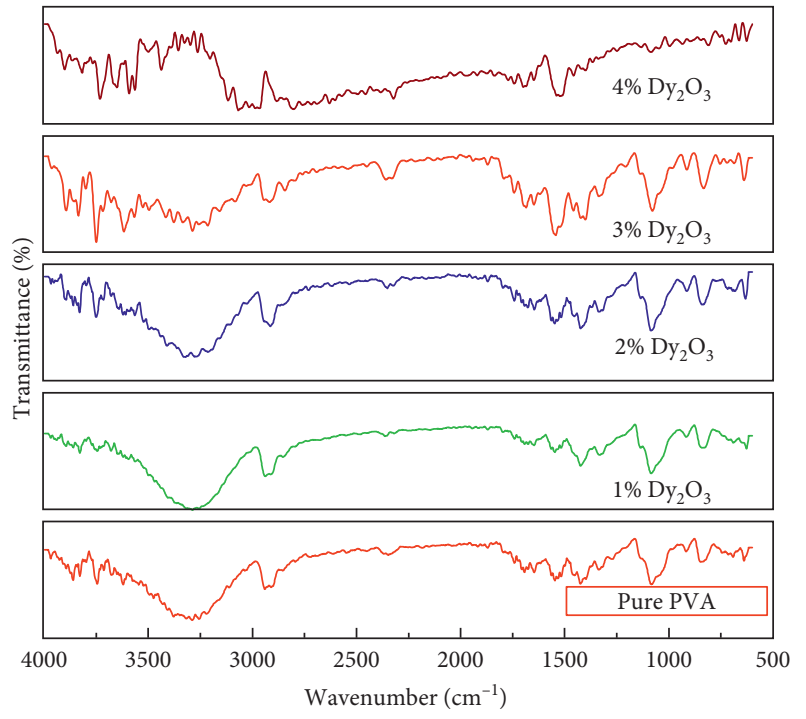

Figure 1: FTIR spectra of PVA $(90 \%)+\mathrm{Na}_{3} \mathrm{C}_{6} \mathrm{H}_{5} \mathrm{O}_{7}(10 \%)+$ nano$\mathrm{Dy}_{2} \mathrm{O}_{3}(1-4 \%)$ films.

using XRD, SEM, DSC, FTIR, and AC impedance spectroscopy, and their utility in electrochemical cell fabrication is probed.

\section{Materials and Methods}

All chemicals, namely, PVA (MW 85,000), $\mathrm{Na}_{3} \mathrm{C}_{6} \mathrm{H}_{5} \mathrm{O}_{7}$, and $\mathrm{Dy}_{2} \mathrm{O}_{3}$ used in the present work were of AR Grade. $\mathrm{Dy}_{2} \mathrm{O}_{3}$ was grinded for $8 \mathrm{hrs}$ in ball milling machine until the size was between 30 and $60 \mathrm{~nm}$. These particles were used in the preset investigation.

The films were casted using solution cast technique [25]. Different proportions of PVA, $\mathrm{Na}_{3} \mathrm{C}_{6} \mathrm{H}_{5} \mathrm{O}_{7}$, and nano- $\mathrm{Dy}_{2} \mathrm{O}_{3}$ as detailed in Tables 1 and 2 were added to triple distilled water and stirred for 48 hours to get a homogenous solution.

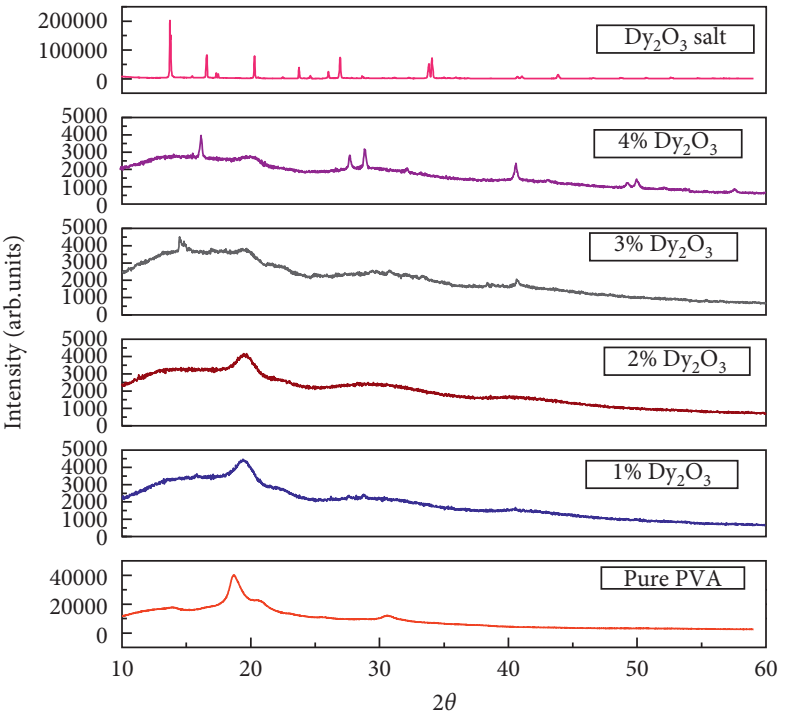

FIGURE 2: XRD pattern of films of PVA $(90 \%)+\mathrm{Na}_{3} \mathrm{C}_{6} \mathrm{H}_{5} \mathrm{O}_{7}(10 \%)$ + nano-Dy $\mathrm{O}_{3}$ PVA (1-4\%) along with pure PVA and $\mathrm{Na}_{3} \mathrm{C}_{6} \mathrm{H}_{5} \mathrm{O}_{7}$.

Then, the solution was poured in Petri dishes, dried at $40^{\circ} \mathrm{C}$ for $24 \mathrm{hrs}$, and then vacuum-dried for $24 \mathrm{hrs}$. The dried films were peeled and characterized with XRD, SEM, FTIR, and DSC, and their electrical properties were measured and presented in Figures 1-7 and Tables 1-3. Further, by using these films as solid polymer electrolytes, electrochemical cells were fabricated, and their characteristics were assessed and presented in Table 4.

FTIR spectra were recorded using Perkin Elmer FTIR Spectrophotometer in the range 4000 to $500 \mathrm{~cm}^{-1}$ adopting $\mathrm{KBr}$ pellet method (with the resolution of $0.5 \mathrm{~cm}^{-1}$ ). The spectra obtained are shown in Figure 1. XRD Bruker D8 instrument with $\mathrm{Cu} \mathrm{K} \alpha$ radiation for $2 \theta$ angles between $10^{\circ}$ and $60^{\circ}$ (with scan rate $2^{\circ} / \mathrm{min}$ and step size $0.02^{\circ}$ ) was used to record spectra of the films, and the obtained spectra are presented in Figure 2. 

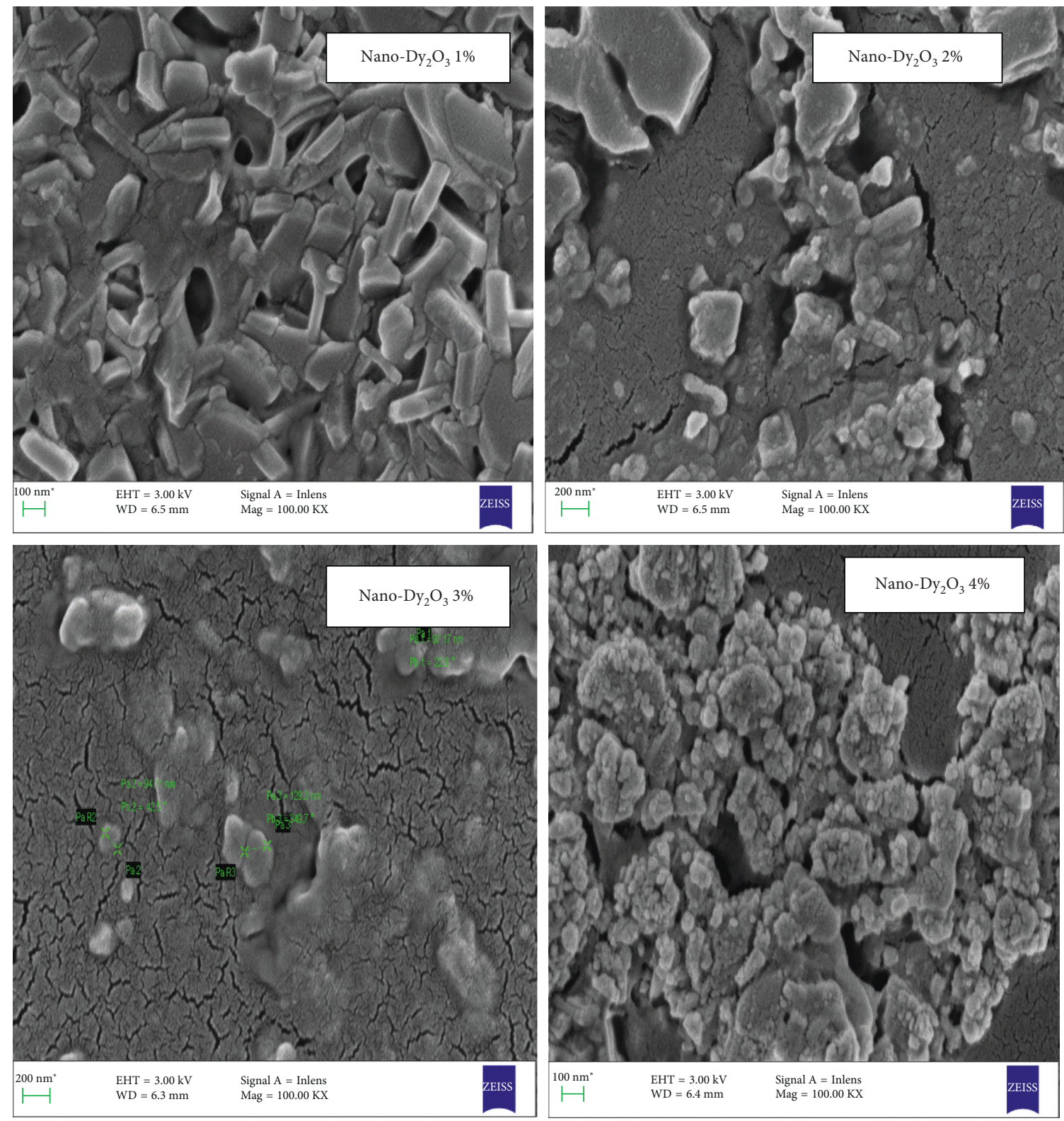

FIgURE 3: SEM images of composite films of PVA (90\%) $+\mathrm{Na}_{3} \mathrm{C}_{6} \mathrm{H}_{5} \mathrm{O}_{7}(10 \%)+$ nano- $\mathrm{Dy}_{2} \mathrm{O}_{3}(1-4 \%)$.

The scanning electron microscope (SEM) images were recorded using FE-SEM (Carl Zeiss, Ultra 55 model) and presented in Figure 3.

Differential scanning calorimeter (DSC) thermograms were recorded using DSC Q20 V24.11 Build 124 for the composite films of PVA $(90 \%)+\mathrm{Na}_{3} \mathrm{C}_{6} \mathrm{H}_{5} \mathrm{O}_{7}(10 \%)+$ nano$\mathrm{Dy}_{2} \mathrm{O}_{3}(1-4 \%)$ films in determining the glass transition and melting temperatures and \% of crystallinity. The results are presented in Figure 4 and Table 1.

The conductivity measurements were carried out using a HIOKI3532-50 impedance analyzer in the frequency range $50 \mathrm{~Hz}$ to $1 \mathrm{MHz}$ at various temperatures of $303 \mathrm{~K}$ to $333 \mathrm{~K}$. The obtained results are presented in Tables 2 and 3 and Figures 5(a) and 5(b).

The transference number measurements were made using Wagner's polarization technique [26] and Watanabe technique [27], and the results are presented in Table 2 and Figure 6. Electrochemical cells were fabricated with the configuration of " $\mathrm{Mg} / \mathrm{MgSO}_{4}$ (anode)/polymer electrolyte/ $\left(\mathrm{I}_{2}+\mathrm{C}+\right.$ electrolyte) (cathode)." The discharge characteristics of the cell like open-circuit voltage (OCV), short-circuit current (SCC), power density, energy density, current capacity, and other parameters were measured under a constant load of $100 \mathrm{k} \Omega$, and the obtained values are presented in Figure 7 and Tables 4 and 5.

\section{Results and Discussion}

Various films synthesized were characterized using various surface morphological techniques and are discussed below. 


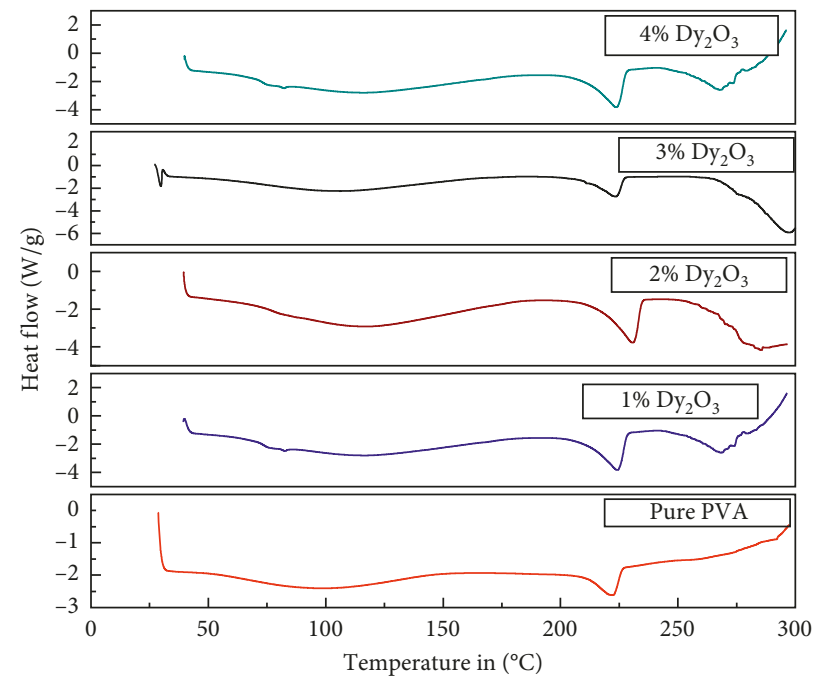

Figure 4: DSC curves of pure PVA and composite films of PVA (90\%) $+\mathrm{Na}_{3} \mathrm{C}_{6} \mathrm{H}_{5} \mathrm{O}_{7}(10 \%)+$ nano- $\mathrm{Dy}_{2} \mathrm{O}_{3}(1-4 \%)$.

TABLE 3: Ionic conductivity values of PVA films at different temperatures.

\begin{tabular}{lcc}
\hline Number & Composition of film: $90: 10: 3 \%$ & Conductivity (S/cm) \\
\hline 1 & $303 \mathrm{~K}$ & $1.06 \times 10^{-4}$ \\
2 & $313 \mathrm{~K}$ & $3.86 \times 10^{-4}$ \\
3 & $323 \mathrm{~K}$ & $6.30 \times 10^{-4}$ \\
4 & $333 \mathrm{~K}$ & $9.72 \times 10^{-4}$ \\
\hline
\end{tabular}

TABLE 4: Cell parameters using the polymer electrolye PVA (90\%) $+\mathrm{Na}_{3} \mathrm{C}_{6} \mathrm{H}_{5} \mathrm{O}_{7}(10 \%)+$ nano- $\mathrm{Dy}_{2} \mathrm{O}_{3}(1-4 \%)$ at constant load of $100 \mathrm{k} \Omega$.

\begin{tabular}{|c|c|c|c|c|c|}
\hline Number & Cell parameters & $\begin{array}{c}\mathrm{PVA}+\mathrm{Na}_{3} \mathrm{C}_{6} \mathrm{H}_{5} \mathrm{O}_{7}+ \\
\text { nano- } \mathrm{Dy}_{2} \mathrm{O}_{3} \\
(90: 10: 1 \%)\end{array}$ & $\begin{array}{c}\mathrm{PVA}+\mathrm{Na}_{3} \mathrm{C}_{6} \mathrm{H}_{5} \mathrm{O}_{7}+ \\
\text { nano- } \mathrm{Dy}_{2} \mathrm{O}_{3} \\
(90: 10: 2 \%)\end{array}$ & $\begin{array}{c}\mathrm{PVA}+\mathrm{Na}_{3} \mathrm{C}_{6} \mathrm{H}_{5} \mathrm{O}_{7}+ \\
\text { nano- }-\mathrm{Dy}_{2} \mathrm{O}_{3} \\
(90: 10: 3 \%)\end{array}$ & $\begin{array}{c}\mathrm{PVA}+\mathrm{Na}_{3} \mathrm{C}_{6} \mathrm{H}_{5} \mathrm{O}_{7}+ \\
\text { nano- } \mathrm{Dy}_{2} \mathrm{O}_{3} \\
(90: 10: 4 \%)\end{array}$ \\
\hline 1 & Open-circuit voltage $(\mathrm{V})$ & 1.96 & 2.37 & 2.68 & 2.14 \\
\hline 2 & Short-circuit current $(\mu \mathrm{A})$ & 230 & 372 & 340 & 260 \\
\hline 3 & Area of the cell $\left(\mathrm{cm}^{2}\right)$ & 1.34 & 1.34 & 1.34 & 1.34 \\
\hline 4 & Weight of the cell (g) & 1.40 & 1.40 & 1.40 & 1.40 \\
\hline 5 & Discharge time $(\mathrm{h})$ & 96 & 108 & 118 & 96 \\
\hline 6 & Power density (W/kg) & 0.32 & 0.62 & 0.91 & 0.39 \\
\hline 7 & Energy density (Wh/kg) & 31.55 & 68 & 107.5 & 38.15 \\
\hline 8 & Current density $\left(\mu \mathrm{A} / \mathrm{cm}^{2}\right)$ & 171.6 & 277 & 253 & 194 \\
\hline 9 & Discharge capacity (mA-hr) & 22.54 & 40.17 & 40.12 & 24.96 \\
\hline
\end{tabular}

3.1. FTIR Analysis. The FTIR spectra of the composite films of various compositions: PVA $(90 \%)+\mathrm{Na}_{3} \mathrm{C}_{6} \mathrm{H}_{5} \mathrm{O}_{7}(10 \%)+$ nano$\mathrm{Dy}_{2} \mathrm{O}_{3}$ PVA (1-4\%), were noted and presented in Figure 1.

The IR data reveal the presence of functional groups like hydroxyl, carbonyl, and carboxylates. The broad peak in pure PVA at $3581-3055 \mathrm{~cm}^{-1}$ with center at $3312 \mathrm{~cm}^{-1}$ pertains to the stretching frequencies of $-\mathrm{OH}$. The broadness indicates the hydrogen bonding between the surface $-\mathrm{OH}$ groups of PVA. With the increase in the $\%$ of nano- $-\mathrm{Dy}_{2} \mathrm{O}_{3}$ in the films, the broadness of the film is decreased, and the position of frequencies are shifted to $3514-3088 \mathrm{~cm}^{-1}$ (with center at $3289 \mathrm{~cm}^{-1}$ ) and $3480-3110 \mathrm{~cm}^{-1}$ (with center at $3267 \mathrm{~cm}^{-1}$ ) with 1 and $2 \%$ of nano- $\mathrm{Dy}_{2} \mathrm{O}_{3}$, respectively. With films having 3 and $4 \%$ of nano- $\mathrm{Dy}_{2} \mathrm{O}_{3}$, sharp peaks are appeared, respectively, at 3602 and $3748 \mathrm{~cm}^{-1}$ for $3 \%$ film and 3580 and $3737 \mathrm{~cm}^{-1}$ for $4 \%$ film. The conversion of broad peak to sharp peaks with change in frequencies as the $\%$ of nano- $\mathrm{Dy}_{2} \mathrm{O}_{3}$ increases may be attributed to the complex formation between the $-\mathrm{OH}$ and nano- $\mathrm{Dy}_{2} \mathrm{O}_{3}$.

Further, there is a shift of $-\mathrm{CH}_{2}$ frequencies from $2944 \mathrm{~cm}^{-1}$ (pure PVA) to $2920 \mathrm{~cm}^{-1}, 2909 \mathrm{~cm}^{-1}, 2887 \mathrm{~cm}^{-1}$, and $2954 \mathrm{~cm}^{-1}$ as the concentration of $\mathrm{Dy}_{2} \mathrm{O}_{3}$ in the film increases from 1 to $4 \%$, respectively. The $-\mathrm{C}-\mathrm{O}-$ stretching frequencies are also shifted from $1098 \mathrm{~cm}^{-1}$ (for pure PVA) to $1073 \mathrm{~cm}^{-1}, 1062 \mathrm{~cm}^{-1}, 1051 \mathrm{~cm}^{-1}$, and $1040 \mathrm{~cm}^{-1}$ as the $\%$ of $\mathrm{Dy}_{2} \mathrm{O}_{3}$ is increased from 1 to $4 \%$, respectively.

The frequencies pertaining to carboxylate ions, namely, 1466 and $1544 \mathrm{~cm}^{-1}$ (in citrates) are shifted to 1308,1420 , and 


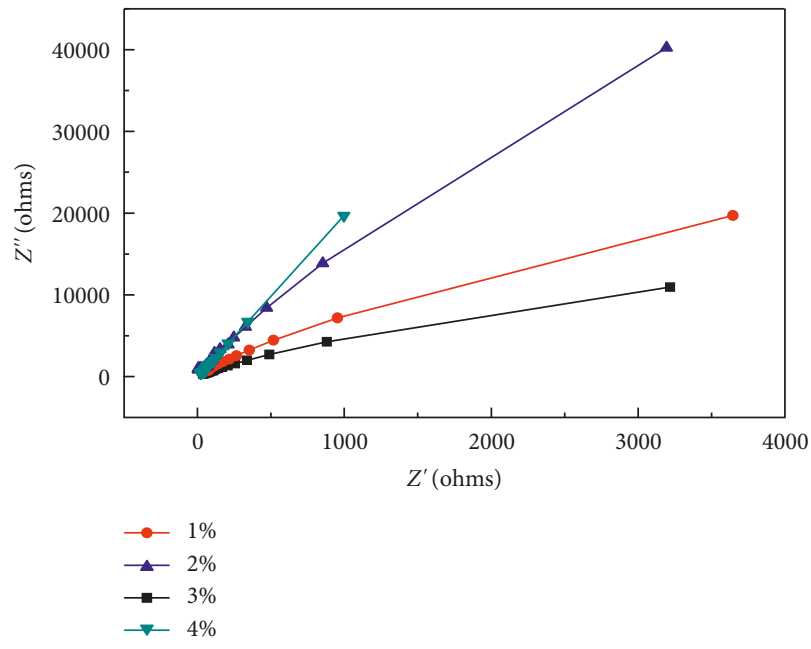

(a)

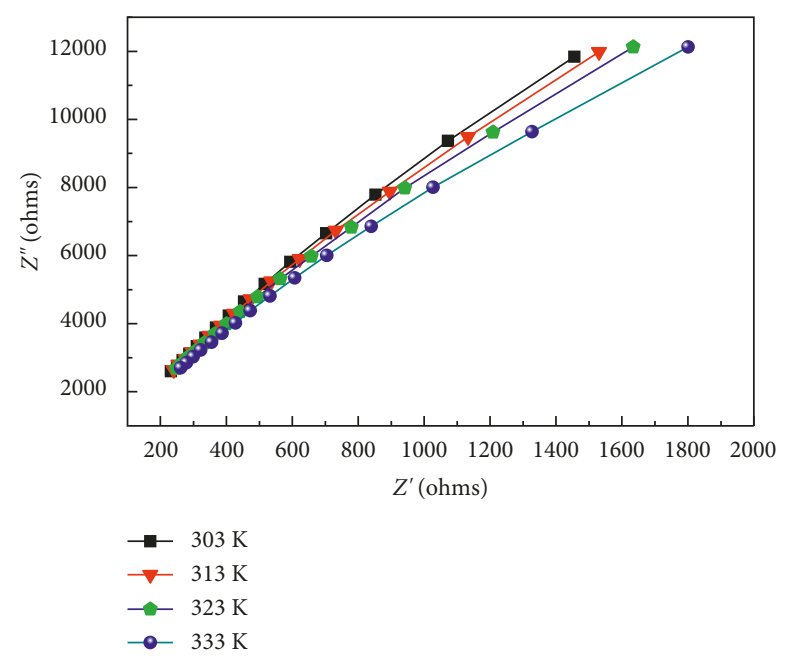

(b)

Figure 5: (a) Impedance plots of PVA: $\mathrm{Na}_{3} \mathrm{C}_{6} \mathrm{H}_{5} \mathrm{O}_{7}$ : nano- $\mathrm{Dy}_{2} \mathrm{O}_{3}(90: 10: 1-4 \%)$ polymer electrolyte films at room temperature. (b) Conductivity plots for PVA $(90 \%)+\mathrm{Na}_{3} \mathrm{C}_{6} \mathrm{H}_{5} \mathrm{O}_{7}(10 \%)+$ nano- $\mathrm{Dy}_{2} \mathrm{O}_{3}(3 \%)$ at different temperatures.

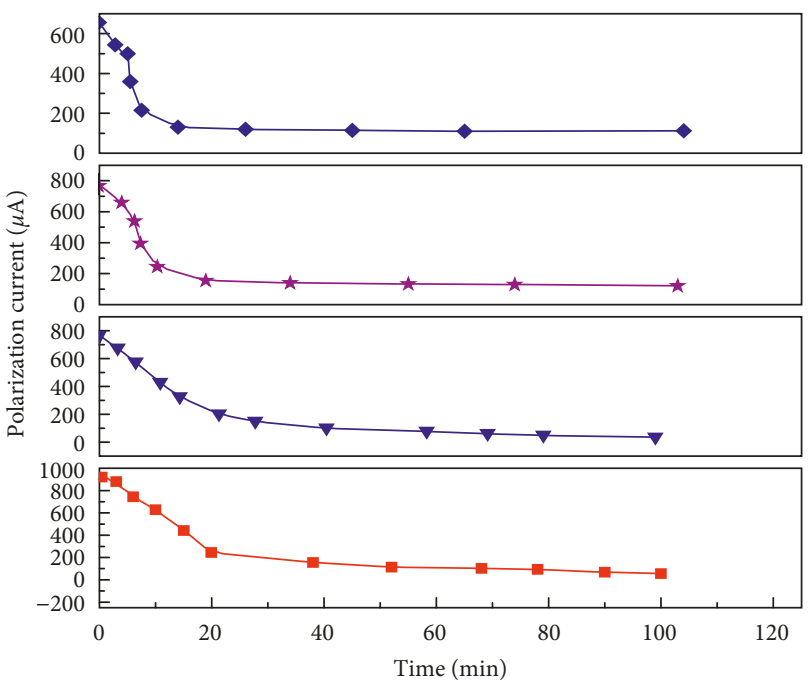

FIgURE 6: Transference number measurements for the composite films PVA $(90 \%)+\mathrm{Na}_{3} \mathrm{C}_{6} \mathrm{H}_{5} \mathrm{O}_{7}(10 \%)+$ nano- $\mathrm{Dy}_{2} \mathrm{O}_{3}(1-4 \%)$.

$1555 \mathrm{~cm}^{-1}$ for $1 \%$; 1331,1421 , and $1577 \mathrm{~cm}^{-1}$ for $2 \% ; 1419,1432$, and $1544 \mathrm{~cm}^{-1}$ for $3 \%$; and 1398,1465 , and $1544 \mathrm{~cm}^{-1}$ for $4 \%$ nano- $\mathrm{Dy}_{2} \mathrm{O}_{3}$-impregnated films. Further, carbonyl group frequencies are also progressively increased towards longer wave side: $1655 \mathrm{~cm}^{-1}$ for $1 \%, 1689 \mathrm{~cm}^{-1}$ for $2 \%, 1667 \mathrm{~cm}^{-1}$ for $3 \%$, and $1700 \mathrm{~cm}^{-1}$ for $4 \%$ nano- $\mathrm{Dy}_{2} \mathrm{O}_{3}$ films. These changes in the frequency positions and their nature, indicate some kind of complex formation between the groups like $-\mathrm{OH}, \mathrm{C}=\mathrm{O}$, and $-\mathrm{COO}^{-}$with the $\mathrm{Dy}_{2} \mathrm{O}_{3}$ and thereby results in the uniform and plasticized films.

3.2. XRD. XRD data of films of different composite are presented in Figure 2.

Pure PVA has broadened the characteristic peak from 18 to $22^{\circ}$, in the $2 \theta$ range (110), while pure nano- $\mathrm{Dy}_{2} \mathrm{O}_{3}$ has well-

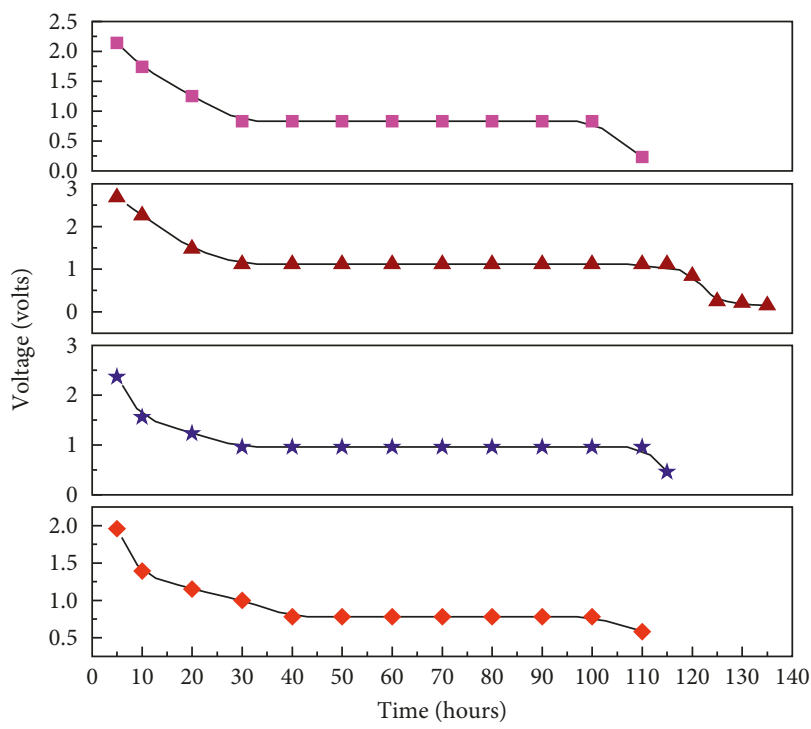

Figure 7: Discharge characteristic plots of PVA (90\%) $+\mathrm{Na}_{3} \mathrm{C}_{6} \mathrm{H}_{5} \mathrm{O}_{7}(10 \%)+$ nano- $\mathrm{Dy}_{2} \mathrm{O}_{3}(1-4 \%)$ electrochemical cell for constant load of $100 \mathrm{k} \Omega$.

defined peaks reflecting its crystalline nature (Figure 2). With the addition of $10 \%$ of sodium citrate salt in the PVA film, the peak is broadened and shifted to $19.0^{\circ}$ with decrease in intensity [34]. Further, in the binary blended films of PVA + sodium citrate, different nano- $\mathrm{Dy}_{2} \mathrm{O}_{3}$ concentrations are doped, and the peaks are shifted with further broadening until the $\%$ of nanoparticles is $3 \%$. With $4 \% \mathrm{Dy}_{2} \mathrm{O}_{3}$ films, again sharp peaks pertaining to $\mathrm{Dy}_{2} \mathrm{O}_{3}$ are noted. This indicates that the film has reached saturation at $3 \%$ of $\mathrm{Dy}_{2} \mathrm{O}_{3}$, and above this concentration, the nanoparticles are precipitating. Further, the broadening of peaks indicate the generation of more amorphous region in the film, which is conducive to the ionic mobility. These changes in the XRD spectrum reflect that the ingredients in the film are homogenously dispersed in the film 
TABLE 5: Comparison of present cell parameters with the data of other cells reported earlier.

\begin{tabular}{|c|c|c|c|c|}
\hline Number & Solid-state electrochemical cell configuration & Open-circuit voltage $(\mathrm{V})$ & Discharge time (hrs) & Reference number \\
\hline 1 & $\mathrm{Ag} /\left(\mathrm{PVP}+\mathrm{AgNO}_{3}\right) /\left(\mathrm{I}_{2}+\mathrm{C}+\right.$ electrolyte $)$ & 0.46 & 82 & [18] \\
\hline 2 & $\mathrm{Ag} /\left(\mathrm{PEO}+\mathrm{AgNO}_{3}\right) /\left(\mathrm{I}_{2}+\mathrm{C}+\right.$ electrolyte $)$ & 0.61 & 48 & {$[28]$} \\
\hline 3 & $\mathrm{Mg} / \mathrm{PEO}+\mathrm{Mg}\left(\mathrm{NO}_{3}\right)_{2} /\left(\mathrm{I}_{2}+\mathrm{C}+\right.$ electrolyte $)$ & 1.85 & 142 & [29] \\
\hline 4 & $\mathrm{~K} /\left(\mathrm{PVP}+\mathrm{PVA}+\mathrm{KBrO}_{3}\right) /\left(\mathrm{I}_{2}+\mathrm{C}+\right.$ electrolyte $)$ & 2.30 & 72 & {$[30]$} \\
\hline 5 & $\mathrm{Mg} / \mathrm{PVA}+\mathrm{Mg}\left(\mathrm{CH}_{3} \mathrm{COO}\right)_{2} /\left(\mathrm{I}_{2}+\mathrm{C}+\right.$ electrolyte $)$ & 1.84 & 87 & {$[31]$} \\
\hline 6 & $\mathrm{~K} /\left(\mathrm{PEO}+\mathrm{KYF}_{4}\right) /\left(\mathrm{I}_{2}+\mathrm{C}+\right.$ electrolyte $)$ & 2.40 & 51 & {$[32]$} \\
\hline 7 & $\mathrm{~K} /\left(\mathrm{PVP}+\mathrm{PVA}+\mathrm{KClO}_{3}\right) /\left(\mathrm{I}_{2}+\mathrm{C}+\right.$ electrolyte $)$ & 2.00 & 52 & {$[33]$} \\
\hline 8 & $\begin{array}{c}\mathrm{Mg}+\mathrm{MgSO}_{4} /\left[\mathrm{PVA}(90 \%)+\mathrm{Na}_{3} \mathrm{C}_{6} \mathrm{H}_{5} \mathrm{O}_{7}(10 \%)+\right. \\
\left.\text { nano- } \mathrm{Dy}_{2} \mathrm{O}_{3}(3 \%)\right] /\left(\mathrm{I}_{2}+\mathrm{C}+\text { electrolyte }\right)\end{array}$ & 2.68 & 118 & Present \\
\hline
\end{tabular}

and that the film containing the $3 \%$ of nano- $\mathrm{Dy}_{2} \mathrm{O}_{3}$ possesses more amorphous regions and more homogenous nature, indicating the suitability of it for conductivity studies.

3.3. SEM Analysis. The SEM images of the films at different concentrations of nano- $\mathrm{Dy}_{2} \mathrm{O}_{3}$ are presented in Figure 3.

It is seen from the images that as the concentration of nano- $\mathrm{Dy}_{2} \mathrm{O}_{3}$ is increased from 1 to $3 \%$ the edges, corners, gaps and so on are decreasing and thereby the homogeneity, so also the amorphous nature, of the film is increased. The more homogenous film is found with $3 \% \mathrm{Dy}_{2} \mathrm{O}_{3}$ film. This increasing homogeneousness is attributed to the bonding between the functional groups of the film, namely, $-\mathrm{OH}$ and $-\mathrm{COO}^{-}$with nano- $\mathrm{Dy}_{2} \mathrm{O}_{3}$. This bonding may be through the occupation of vacant coordinating sites of $\mathrm{Dy}_{2} \mathrm{O}_{3}$ or due to some sort of hydrogen bonding such as " $\mathrm{Dy}=\mathrm{O} \ldots \mathrm{H}-\mathrm{O}$ ” or "Dy-OH . . O OC-." When the \% of $\mathrm{Dy}_{2} \mathrm{O}_{3}$ is more than $3 \%$, again edges, boundaries, and holes are appeared, indicating the precipitation of undissolved nano- $\mathrm{Dy}_{2} \mathrm{O}_{3}$ in the film. These inferences are supported by XRD data.

3.4. DSC Studies. For assessing the degree of crystallinity, differential scanning calorimeter (DSC) investigations were undertaken, and the obtained results are presented in Figure 4 and Table 1. $T_{\mathrm{g}}$ and $M_{\mathrm{p}}$ were evaluated from graphs (Figure 4).

Percentage of crystallinities of the films were calculated using the equation: $\% \chi_{\mathrm{c}}=\left\{\left(\Delta H_{\mathrm{m}}\right) /\left(\Delta H_{\mathrm{m}}^{0}\right)\right\} \times 100$, where $\Delta H_{\mathrm{m}}^{0}$ is the melting enthalpy of PVA : sodium citrate $(90: 10)$ film and $\Delta H_{\mathrm{m}}$ is the melting enthalpy of related composite films containing nano- $\mathrm{Dy}_{2} \mathrm{O}_{3}$ at varied percentages [35]. The glass transition temperature $\left(T_{\mathrm{g}}\right)$, melting temperature $\left(T_{\mathrm{m}}\right)$, and relative percentage of crystallinity $\left(\% \chi_{\mathrm{c}}\right)$ values are presented in Table 1.

At $3 \%$ of nano- $\mathrm{Dy}_{2} \mathrm{O}_{3}$, the crystallinity is lowest, and the film is more homogenous and plasticized with more amorphous nature. This kind of structure provides more paths to proton transport in the film and hence more conductivity.

3.5. Impedance Analysis. The conductivity of the different films was measured by sandwiching PVA $(90 \%)+\mathrm{Na}_{3} \mathrm{C}_{6} \mathrm{H}_{5} \mathrm{O}_{7}$ $(10 \%)+$ nano- $\mathrm{Dy}_{2} \mathrm{O}_{3}(1-4 \%)$ films between thin stainless steel plates using HIOKI3532-50 impedance analyzer at temperature $303 \mathrm{~K}$. The conductivity was calculated using the formula: $\sigma=l=R_{b} / A$ in S/cm, where $\sigma=$ ionic conductivity, $l=$ thickness of the polymer electrolyte film, $R_{b}=$ bulk resistance, and $A=$ area of the stainless steel electrode, contacting the polymer electrolyte film.

Findings are presented in Figures 5(a) and 5(b) and Table 2. Further, the conductivities at various temperatures were measured (using $\mathrm{HIOKI} 3532-50$ impedance analyzer) for the PVA $(90 \%)+\mathrm{Na}_{3} \mathrm{C}_{6} \mathrm{H}_{5} \mathrm{O}_{7}(10 \%)+$ nano- $-\mathrm{Dy}_{2} \mathrm{O}_{3}$ PVA (3\%) film in view of the fact that the said film was showing higher conductivity.

It is observed from Figure 5(a) that the absence of highfrequency semicircle portion reflects the charge carriers are ions. The presence of nano- $\mathrm{Dy}_{2} \mathrm{O}_{3}$ in the films has remarkably increased the conductivity of the films. The conductivity of pure PVA is of the order $10^{-10} \mathrm{~S} / \mathrm{cm}$ [28]. Increase in conductivity is found with increase in concentration of nano- $\mathrm{Dy}_{2} \mathrm{O}_{3}$, and the conductivity reached maximum at $3 \%$ and any further increase causes the decrease of conductivity: $5.31 \times 10^{-5}$ with $1 \% ; 4.48 \times 10^{-5}$ with $2 \%$; $1.06 \times 10^{-4}$ with $3 \%$, and $3.26 \times 10^{-6}$ with $4 \%$.

The nano- $\mathrm{Dy}_{2} \mathrm{O}_{3}$ by virtue of possessing high surface area, quantum confinements, paramagnetic nature, and bonding tendencies of accepting electrons (Lewis acidic nature) from donor atoms of the surface functions groups influences the conductivity of the composite films [36]. Moreover, the bonding results in cross-linking PVA $+\mathrm{Na}_{3} \mathrm{C}_{6} \mathrm{H}_{5} \mathrm{O}_{7}$ segments through the bonding tendencies of nano- $\mathrm{Dy}_{2} \mathrm{O}_{3}$ and thereby generates additional pathways in the film that complements the ionic movement [22-24]. Thus, acquired homogeneity in more plasticized films brings some kind of order in the films, and this facilitates easy movement of the charge carriers that results in the enhancement of conductivity. It seems that $\mathrm{PVA}+\mathrm{Na}_{3} \mathrm{C}_{6} \mathrm{H}_{5} \mathrm{O}_{7}(90: 10)$ film is statured with nano- $\mathrm{Dy}_{2} \mathrm{O}_{3}$ at $3 \%$ and any further increase results in the precipitation of the nanoparticles in the pathways, thereby blocking short ways in the polymer matrix for the movement of ions. This results in low conductivity. It may be noted that the activation energy is minimum in the composite film having $3 \%$ of nano- $\mathrm{Dy}_{2} \mathrm{O}_{3}$ with a value of $0.19 \mathrm{~V}$ (Table 1 ).

Further, the bulk resistance decreases with increase in temperature, and this results in the enhancement of the conductivity. At $303 \mathrm{~K}$, the conductivity is $1.06 \times 10^{-4} \mathrm{~S} / \mathrm{cm}$, while at $333 \mathrm{~K}$, it is $9.72 \times 10^{-4} \mathrm{~S} / \mathrm{cm}$ (vide Table 3 ). This increase in conductivity may be attributed to the hopping of interchain and intrachain ion movements and also due to 
decrease in microscopic viscosity at interface in solid polymer electrolyte matrixes.

3.6. Transference Numbers. For the classification of polymer electrolyte films, ionic transference number is considered to be one of the most significant parameters. By using Wagner's polarizing technique, the transference numbers for the films were measured by constructing a system of $\mathrm{Mg} /$ (PVA $\left.+\mathrm{Na}_{3} \mathrm{C}_{6} \mathrm{H}_{5} \mathrm{O}_{7}+\mathrm{Dy}_{2} \mathrm{O}_{3}\right) / \mathrm{C}$ and polarizing it at $303 \mathrm{~K}$ at a constant dc potential of $1.5 \mathrm{~V}$ in order to assess the contributions of ions and electrons to the entire conductivity of the polymer electrolyte films. The equations used were

$$
t_{\text {ion }}=\frac{I_{\text {initial }}-I_{\text {final }}}{I_{\text {initial }}}=\frac{I_{\text {total }}-I_{\text {electronic }}}{I_{\text {total }}}=\frac{I_{\text {ionic }}}{I_{\text {total }}},
$$

where $I_{\text {initial }}$ is the initial current and $I_{\text {final }}$ is the final current. The ionic transference number $\left(t_{\text {ion }}\right)$ values were in the range 0.93-0.98. The results are presented in Figure 6 and Table 2.

It is seen from Table 2 that the charge carriers are predominantly ions in all the composite films, and the contribution of electrons is very minute. For the composite films containing 3.0\% of $\mathrm{Dy}_{2} \mathrm{O}_{3}$, more conductivity is observed and in fact, at that composition, the film has low activation energy and crystallinity. Further, the ionic transference numbers $\left(t_{\text {ion }}\right)$ of the films are near to unity, indicating their suitability as a polymer electrolyte for solid-state electrochemical cells [25-27].

3.7. Discharge Studies. The solid-state electrochemical cells were fabricated with the configuration "anode $(\mathrm{Mg}$ $\left.+\mathrm{MgSO}_{4}\right) /\left[\mathrm{PVA}(90 \%)+\mathrm{Na}_{3} \mathrm{C}_{6} \mathrm{H}_{5} \mathrm{O}_{7}(10 \%)+\right.$ nano- $-\mathrm{Dy}_{2} \mathrm{O}_{3}$ (1-4\%)]/cathode $\left(\mathrm{I}_{2}+\mathrm{C}+\right.$ electrolyte)." The thickness of both the electrodes was $1 \mathrm{~mm}$, while the surface area and thicknesses of the "PVA $+\mathrm{Na}_{3} \mathrm{C}_{6} \mathrm{H}_{5} \mathrm{O}_{7}$ + nano- $\mathrm{Dy}_{2} \mathrm{O}_{3}$ " polymer electrolyte were $1.34 \mathrm{~cm}^{2}$ and $150 \mu \mathrm{m}$, respectively. The presence of carbon in the cathode increases the conductivity, and polyelectrolyte reduces the resistance by allowing more interfacial contact between the cathode and electrolyte [35]. The discharge characteristics, namely, opencircuit voltage $(\mathrm{OCV})$, short-circuit current (SCC), current density, power density, energy density, discharge time, and discharge capacity of the cell for a constant load of $100 \mathrm{k} \Omega$ were evaluated at room temperature and are shown in Figure 7 and Table 4.

It is seen from the data that the film with $3 \%$ of nano$\mathrm{Dy}_{2} \mathrm{O}_{3}$ shows better discharge characters: discharge time: $118 \mathrm{~h}$; energy density: $107.5 \mathrm{Wh} / \mathrm{kg}$; power density: $0.91 \mathrm{~W} / \mathrm{kg}$; and open-circuit voltage: $2.68 \mathrm{~V}$. These indicate that these composite films loaded with optimum amounts of nano- $\mathrm{Dy}_{2} \mathrm{O}_{3}$ can be successfully adopted as polyelectrolyte films in the battery applications.

\section{Comparison with Previous Work}

The electrochemical cell developed in this work is compared with the works available in the literature, and a comparative statement is presented in Table 5 .
It is inferred from Table 5 that the present developed solid-state electrolyte system is more efficient than many reported in the literature with respect to simplicity, efficiency, reliability, and good discharge times besides being economical and environment friendly. These systems find applications as cost-effective electrolytes in high-density solid-state electrochemical cells.

\section{Conclusions}

Nano- $\mathrm{Dy}_{2} \mathrm{O}_{3}$-doped polymer electrolyte films of composition "PVA $(90 \%)+$ sodium citrate $(10 \%)+$ nano- $\mathrm{Dy}_{2} \mathrm{O}_{3}$ (1 to $\left.4 \%\right)$ " are synthesized by solution cast technique. The films are found to be good, stable, and endowed with excellent plasticity.

The films surface morphological characteristics and other physicochemical features are assessed by using FTIR, XRD, and SEM methods. The studies reveal that the different components in the film are homogenously and completely dispersed. It is attributed to the bonding tendencies of various functional groups present in PVA and sodium citrate such as $-\mathrm{OH}$ and $-\mathrm{COO}^{-}$with the $\mathrm{Dy}_{2} \mathrm{O}_{3}$. This binding nature helps to form a kind of surface complex, which is conducive for the movement of ions. The optimum $\%$ of $\mathrm{Dy}_{2} \mathrm{O}_{3}$ for forming more homogenous and less crystalline film is found to be $3 \%$. Even DSC investigations reveal that at $3.0 \%$ of nano- $\mathrm{Dy}_{2} \mathrm{O}_{3}$, the amorphous region of the film is more, and this enables the ions to penetrate more in the film, thereby increasing the conductivity of the films.

The presence of nano- $-\mathrm{Dy}_{2} \mathrm{O}_{3}$ remarkably enhances the conductivity of these PVA-based films. The conductivity for pure PVA film is $5.59 \times 10^{-10} \mathrm{~S} / \mathrm{cm}$ at $303 \mathrm{~K}$. But the conductivity is increased to $5.31 \times 10^{-5}, 4.48 \times 10^{-5}, 1.06 \times 10^{-4}$, and $3.26 \times 10^{-6} \mathrm{~S} / \mathrm{cm}$ (at $303 \mathrm{~K}$ ) with the films containing $1 \%, 2 \%$, $3 \%$, and $4 \%$ of nano- $-\mathrm{Dy}_{2} \mathrm{O}_{3}$, respectively. With the increase in temperature, the conductivity is increased: $1.06 \times 10^{-4} \mathrm{~S} / \mathrm{cm}$ at $303 \mathrm{~K} ; 3.86 \times 10^{-4} \mathrm{~S} / \mathrm{cm}$ at $313 \mathrm{~K} ; 6.30 \times 10^{-4} \mathrm{~S} / \mathrm{cm}$; at $323 \mathrm{~K}$; and $9.72 \times 10^{-4} \mathrm{~S} / \mathrm{cm}$ at $333 \mathrm{~K}$. This enhancement in conductivity is due to the hopping of interchain and intrachain ion movements and falling of microscopic viscosity at the matrix interface of the film. The studies on transference numbers reveal that the charge carriers are ions, and the contribution of electrons is almost negligible.

These polymer electrolyte films are investigated for their utility by constructing electrochemical cell with the configuration "anode $\left(\mathrm{Mg}+\mathrm{MgSO}_{4}\right) /\left[\mathrm{PVA}(90 \%)+\mathrm{Na}_{3} \mathrm{C}_{6} \mathrm{H}_{5} \mathrm{O}_{7}\right.$ $(10 \%)+\left(1-4 \%\right.$ nano- $\left.\left.\mathrm{Dy}_{2} \mathrm{O}_{3}\right)\right] /$ cathode $\left(\mathrm{I}_{2}+\mathrm{C}+\right.$ electrolyte)." The various discharge characteristics are evaluated and found that the films with $3 \%$ nano- $-\mathrm{Dy}_{2} \mathrm{O}_{3}$ have maximum discharge time of $118 \mathrm{hrs}$, open-circuit voltage of $2.68 \mathrm{~V}$, power density of $0.91 \mathrm{~W} / \mathrm{kg}$, and energy density of $107.5 \mathrm{Wh} / \mathrm{Kg}$. These good findings emphasize the successful adoption of the developed polymer electrolyte films. These films may find good utility in solid-state battery applications.

\section{Conflicts of Interest}

The authors declare that there are no conflicts of interest regarding the publication of this paper. 


\section{Authors' Contributions}

All authors have contributed significantly to this work.

\section{Acknowledgments}

The authors thank the K L University authorities for providing the necessary facilities and financial help to carry out this research work.

\section{References}

[1] J. C. Lasseques and P. Colombon, Proton Conductors: Solids, Membranes and Gels, University Press, Cambridge, UK, 1992.

[2] C. S. Ramya, S. Selvasekarapandian, T. Savitha et al., "Conductivity and thermal behavior of proton conducting polymer electrolyte based on poly ( $N$-vinyl pyrrolidone)," European Polymer Journal, vol. 42, no. 10, pp. 2672-2677, 2006.

[3] B. Smitha, S. Sridhar, and A. A. Khan, "Chitosan-sodium alginate polyion complexes as fuel cell membranes," European Polymer Journal, vol. 41, no. 8, pp. 1859-1866, 2005.

[4] N. Srivastava and S. Chandra, "Studies on a new proton conducting polymer system: poly(ethylene succinate) $+\mathrm{NH}_{4} \mathrm{ClO}_{4}$," European Polymer Journal, vol. 36, no. 2, pp. 421-433, 2000.

[5] H. T. Pu and D. Wang, "Studies on proton conductivity of polyimide/H3PO4/imidazole blends," Electrochimica Acta, vol. 51, no. 26, pp. 5612-5617, 2006.

[6] M. M. Coleman and P. C. Painter, "Hydrogen bonded polymer blends," Progress in Polymer Science, vol. 20, no. 1, pp. 1-59, 1995.

[7] T. Kanbara, M. Inami, and T. Yamamoto, "New solid-state electric double-layer capacitor using poly(vinyl alcohol)based polymer solid electrolyte," Journal of Power Sources, vol. 36, no. 1, pp. 87-93, 1991.

[8] H. A. Every, F. Zhou, M. Forsyth, and D. R. MacFarlane, "Lithium ion mobility in poly(vinyl alcohol) based polymer electrolytes as determined by 7Li NMR spectroscopy," Electrochimica Acta, vol. 43, no. 10-11, pp. 1465-1469, 1998.

[9] D. Kumar and S. A. Hashmi, "Ion transport and ion-fillerpolymer interaction in poly(methyl methacrylate)-based, sodium ion conducting, gel polymer electrolytes dispersed with silica nanoparticles," Journal of Power Sources, vol. 195, no. 15 , pp. 5101-5108, 2010.

[10] F. Croce, L. Persi, B. Scrosati, F. Serraino-Fiory, E. Plichta, and M. A. Hen-drickson, "Role of the ceramic fillers in enhancing the transport properties of composite polymer electrolytes," Electrochimica Acta, vol. 46, no. 16, pp. 2457-2461, 2001.

[11] Z. Li, G. Su, D. Gao, X. Wang, and X. Li, "Effect of $\mathrm{Al}_{2} \mathrm{O}_{3}$ nanoparticles on the electrochemical characteristics of P(VDF-HFP)-based polymer electrolyte," Electrochimica Acta, vol. 49, no. 26, pp. 4633-4639, 2004.

[12] C. C. Tambelli, A. C. Bloise, A. V. Rosario, E. C. Pereira, C. J. Magon, and J. P. Donosa, "Characterisation of PEO$\mathrm{Al}_{2} \mathrm{O}_{3}$ composite polymer electrolytes," Electrochimica Acta, vol. 47, no. 11, pp. 1677-1682, 2002.

[13] P. A. R. D. Jayathilaka, M. A. K. L. Dissanayake, I. Albinsson, and B.-E. Mel-lander, "Effect of nano-porous $\mathrm{Al}_{2} \mathrm{O}_{3}$ on thermal, dielectric and transport properties of the (PEO) ${ }_{9}$ LiTFSI polymer electrolyte system," Electrochimica Acta, vol. 47, no. 20, pp. 3257-3268, 2002.

[14] M. A. K. L. Dissanayake, P. A. R. D. Jayathilaka, R. S. P. Bokalawala, I. Albinsson, and B.-E. Mellander, "Effect of concentration and grain size of alumina filler on the ionic conductivity enhancement of the $(\mathrm{PEO})_{9} \mathrm{LiCF}_{3} \mathrm{SO}_{3}: \mathrm{Al}_{2} \mathrm{O}_{3}$ composite polymer electrolyte," Journal of Power Sources, vol. 119-121, pp. 409-414, 2003.

[15] C. H. Park, D. W. Kim, J. Prakash, and Y.-K. Sun, "Electrochemical stability and conductivity enhancement of composite polymer electrolytes," Solid State Ionics, vol. 159, no. 1-2, pp. 111-119, 2003.

[16] B. Kumar, S. J. Rodrigues, and S. Koka, "The crystalline to amorphous transition in PEO-based composite electrolytes: role of lithium salts," Electrochimica Acta, vol. 47, no. 25, pp. 4125-4131, 2002.

[17] Y. Liu, J. Y. Lee, and L. Hong, "Functionalized $\mathrm{SiO}_{2}$ in poly (ethylene oxide)-based polymer electrolytes," Journal of Power Sources, vol. 109, no. 2, pp. 507-514, 2002.

[18] L. Fan, C. W. Nan, and S. Zhao, "Effect of modified $\mathrm{SiO}_{2}$ on the properties of PEO-based polymer electrolytes," Solid State Ionics, vol. 164, no. 1-2, pp. 81-86, 2003.

[19] H. M. Xiong, K. K. Zhao, X. Zhao, Y. W. Wang, and J. S. Chen, "Elucidating the conductivity enhancement effect of nanosized $\mathrm{SnO}_{2}$ fillers in the hybrid polymer electrolyte PEO-SnO ${ }_{2}-\mathrm{LiClO}_{4}$," Solid State Ionics, vol. 159, no. 1-2, pp. 89-95, 2003.

[20] L. Fan, Z. Dang, G. Wei, C. W. Nan, and M. Li, "Effect of nanosized $\mathrm{ZnO}$ on the electrical properties of $(\mathrm{PEO})_{16} \mathrm{LiClO}_{4}$ electrolytes," Materials Science and Engineering: B, vol. 99, no. 1-3, pp. 340-343, 2003.

[21] J. Adebahr, N. Byrne, M. Forsyth, D. R. MacFarlane, and P. Jacobsson, "Enhancement of ion dynamics in PMMA-based gels with addition of $\mathrm{TiO}_{2}$ nano-particles," Electrochimica Acta, vol. 48, no. 14-16, pp. 2099-2103, 2003.

[22] B. Kumar, S. J. Rodrigues, and L. G. Scanlon, "Poly(ethylene oxide)-based composite electrolytes: crystalline $\rightleftharpoons$ amorphous transition," Journal of The Electrochemical Society, vol. 148, no. 12, p. A1191, 2001.

[23] J. D. Kim and I. Honma, "Proton conducting polydimethylsiloxane/zirconium oxide hybrid membranes added with phosphotungstic acid," Electrochimica Acta, vol. 48, no. 24, pp. 3633-3638, 2003.

[24] A. D'epifanio, F. S Fiory, S. Licoccia, E. Traversa, and B. Scrosati, "Metallic-lithium, $\mathrm{LiFePO}_{4}$-based polymer battery using $\mathrm{PEO}-\mathrm{ZrO}_{2}$ nanocomposite polymer electrolyte," Journal of Applied Electrochemistry, vol. 34, pp. 403-408, 2004.

[25] M. White, "Thin polymer films," Thin Solid Films, vol. 18, no. 2, pp. 157-172, 1973.

[26] J. B. Wagner and C. J. Wagner, "Electrical conductivity measurements on cuprous halides," Journal of Chemical Physics, vol. 20, p. 1597, 1957.

[27] M. Watanabe, S. Nagano, K. Sanui, and N. Ogata, "Estimation of $\mathrm{Li}+$ transport number in polymer electrolytes by the combination of complex impedance and potentiostatic polarization measurements," Solid State Ionics, vol. 28-30, pp. 911-917, 1988.

[28] A. Lewandowski, M. Zajder, E. Frackowiak, and F. Beguin, "Supercapacitor based on activated carbon and polyethylene oxide- $\mathrm{KOH}-\mathrm{H}_{2} \mathrm{O}$ polymer electrolyte," Electrochimica Acta, vol. 46, no. 18, pp. 2777-2780, 2001.

[29] M. J. Reddy and U. V. SubbaRao, "Transport studies of poly (ethylene oxide)-based polymer electrolyte complexed with sodium yttrium fluoride," Journal of Materials Science Letters, vol. 17, no. 19, pp. 1613-1615, 1998.

[30] P. Balaji Bhargav, V. Madhu Mohan, A. K. Sharma, and V. V. R. N. Rao, "Investigations on electrical properties of (PVA: $\mathrm{NaF}$ ) polymer electrolytes for electrochemical cell applications," Current Applied Physics, vol. 9, no. 1, pp. 165-171, 2009. 
[31] R. M. Hodge, G. H. Edward, and G. P. Simon, "Water absorption and states of water in semicrystalline poly(vinyl alcohol) films," Polymer, vol. 37, no. 8, pp. 1371-1376, 1996.

[32] P. Anji Reddy and R. Kumar, "Ionic conductivity and discharge characteristic studies of PVA- $\mathrm{Mg}\left(\mathrm{CH}_{3} \mathrm{COO}\right)_{2}$ solid polymer electrolytes," International Journal of Polymeric Materials, vol. 62, no. 2, pp. 76-80, 2012.

[33] C. V. Subba Reddy, A. K. Sharma, and V. V. R Narasimha Rao, "Effect of plasticizer on electrical conductivity and cell parameters of $\mathrm{PVP}+\mathrm{PVA}+\mathrm{KClO}_{3}$ blend polymer electrolyte system," Journal of Power Sources, vol. 111, no. 2, pp. 357-360, 2002.

[34] J. Ramesh Babu, K. Ravindhranath, and K. Vijaya Kumar, "Structural and electrical properties of sodium citrate doped poly(vinyl alcohol) films for electrochemical cell applications," Asian Journal of Chemistry, vol. 29, no. 5, pp. 10491055, 2017.

[35] M. Hema, S. Selvasekerapandian, G. Hirankumar, A. Sakunthala, D. Arunkumar, and H. J. Nithya, "Structural and thermal studies of PVA: $\mathrm{NH}_{4} \mathrm{I}$," Journal of Physics and Chemistry of Solids, vol. 70, no. 7, pp. 1098-1103, 2009.

[36] K. Kattel, J. Y. Park, W. Xu et al., "Paramagnetic dysprosium oxide nanoparticles and dysprosium hydroxide nanorods as T2 MRI contrast agents," Biomaterials, vol. 33, no. 11, pp. 3254-3261, 2012. 


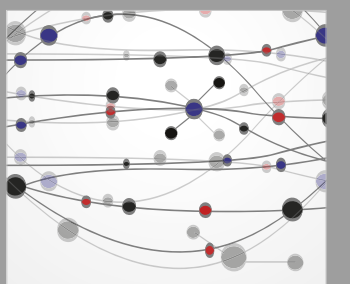

The Scientific World Journal
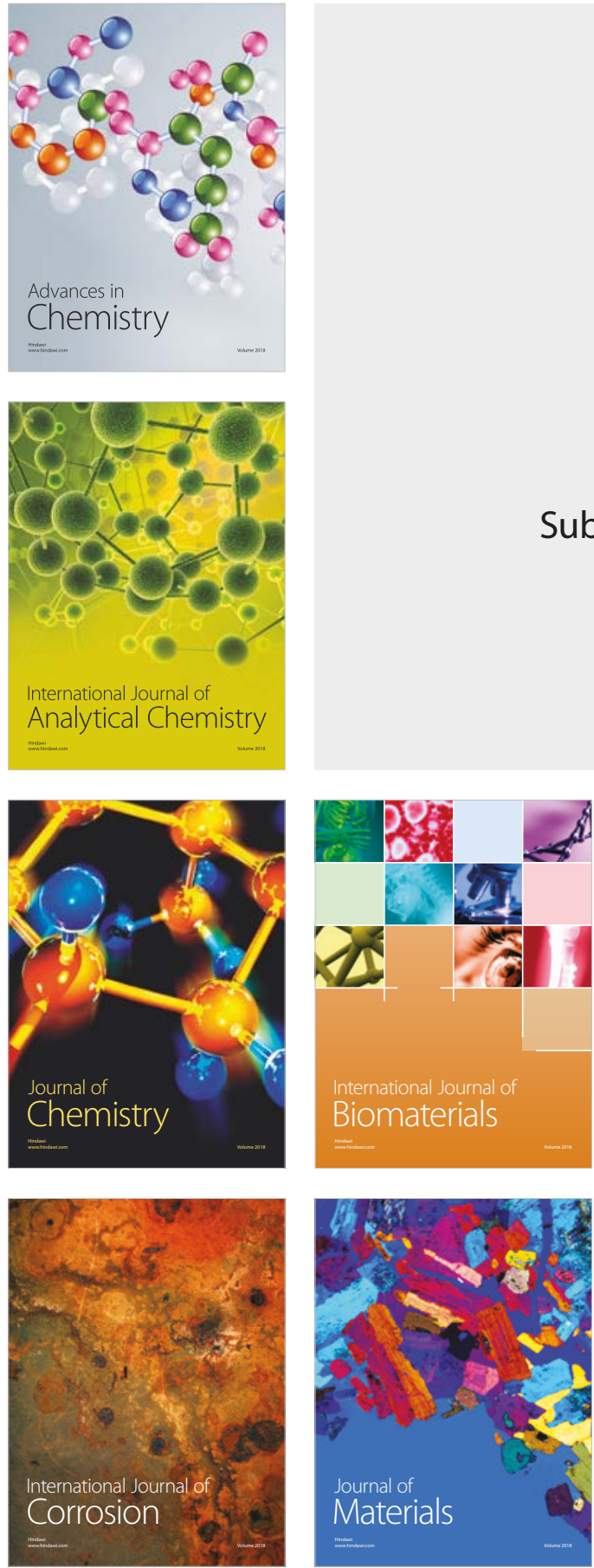

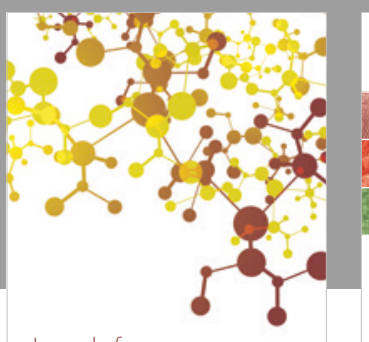

Journal of

Applied Chemistry
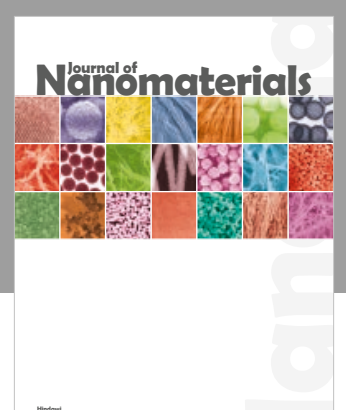

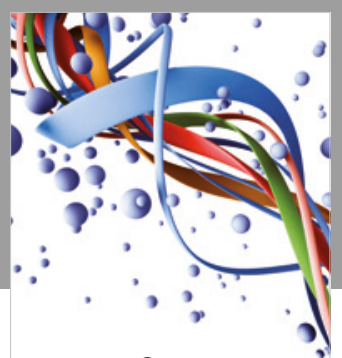

Scientifica

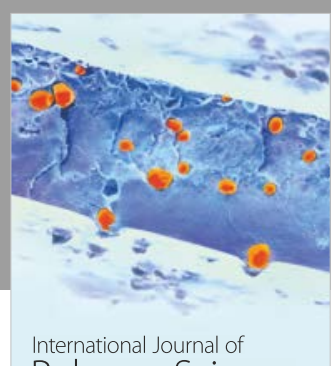

Polymer Science

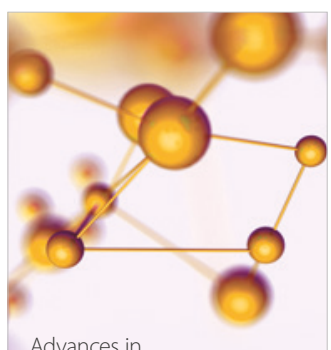

Physical Chemistry
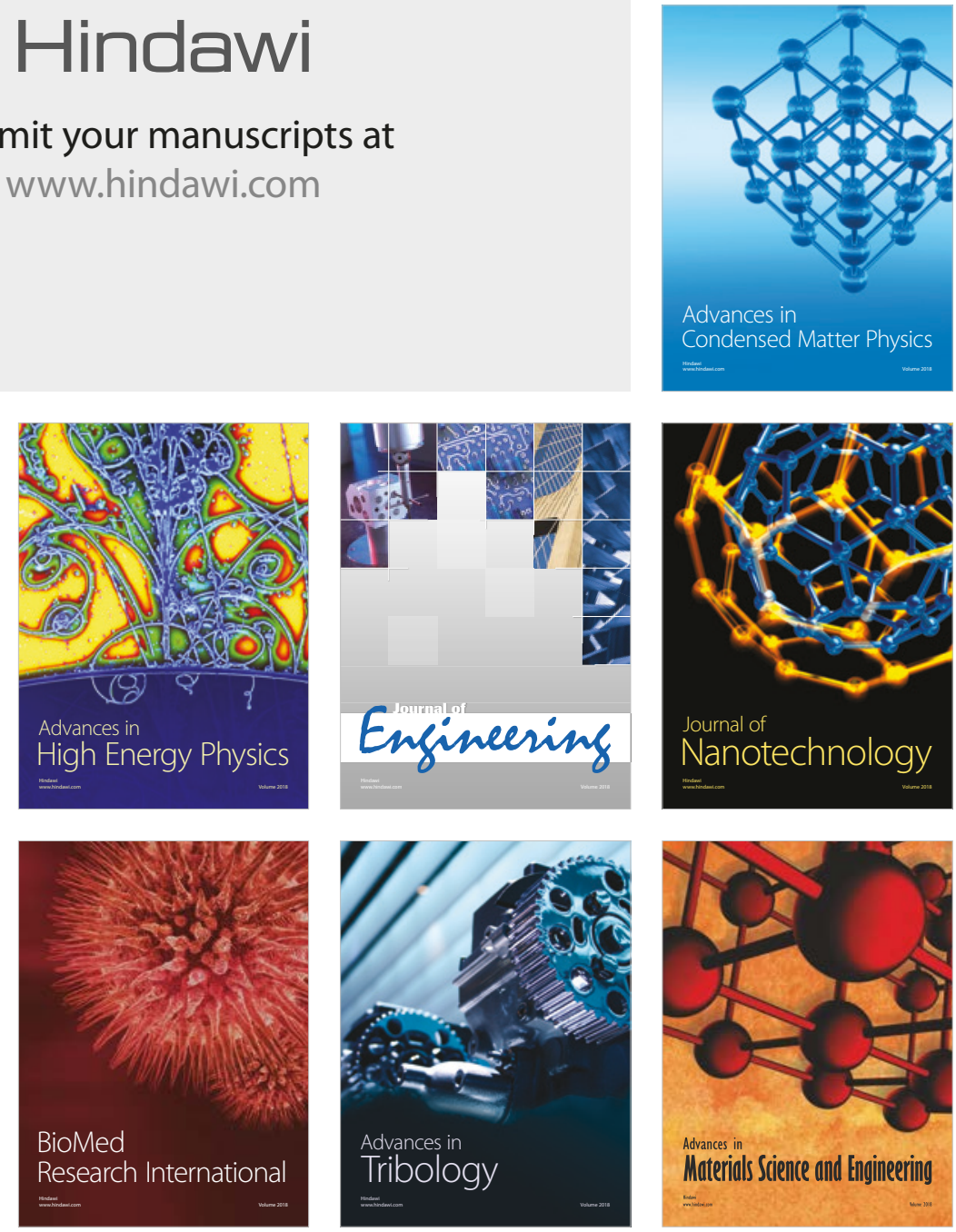